DOI 10.22394/2073-2929-2021-01-68-80

\title{
Fear of Crime among Mongolians in the Ulaanbaatar Metropolitan Area
}

\author{
Chuluunbat Sharkhuu ${ }^{\mathrm{a},}{ }^{*}$, Min-Sik Lee ${ }^{\mathrm{b}}$ \\ a Mongolian Institute for Protection and Security Studies, Ulaanbaatar, Mongolia, mongolianipss@gmail.com \\ b Kyonggi University, Suwon, South Korea, Imspu@kyonggi.ac.kr
}

\section{ABSTRACT}

This study is about fear of crime, which is one of the most important topics in the criminological research. The study tested an integrated model in structural equation modeling method by using both SPSS and AMOS. Those who perceive higher levels of incivility were found to be more fearful of crime. Policies to reduce fear of crime and implications for future research were discussed based on the findings.

Keywords: Fear of Crime, Integrated Model, Policy Implications

For citing: Chuluunbat Sharkhuu, Min-Sik Lee. Fear of Crime among Mongolians in the Ulaanbaatar Metropolitan Area // Eurasian Integration: economic, law, politics. 2021. No. 1. Pp. 68-80.

\section{Страх перед преступностью среди монголов на примере агломерации Улан-Батора: тестирование интегрированной модели}

\author{
Чулуунбат Шархуу ${ }^{1,}{ }^{*}$, Мин-Сик И $^{2}$ \\ ${ }^{1}$ Институт исследования защиты и безопасности Монголии, Улан-Батор, Монголия; mongolianipss@ \\ gmail.com \\ ${ }^{2}$ Университет Кионгги, Сувон, Южная Корея; Imspu@kyonggi.ac.kr
}

\section{PЕФЕРАТ}

В настоящем исследовании рассмотрен вопрос о страхе граждан перед преступностью, являющейся важной темой исследования криминологии. В ходе исследования использована интегрированная модель анализа в способе структурного моделирования уравнения по программному обеспечению SPSS и AMOS.

Результаты исследования показывают, что страх граждан перед преступностью в большей мере зависит от необустройства окружающей среды. На основе полученных результатов авторы обсудили политику по снижению страха перед преступностью и ее последствиями для будущих исследований, сделали выводы и внесли предложения.

Ключевые слова: страх перед преступностью, интегрированная модель, практические выводы

Для цитирования: Чулуунбат Шархуу, Мин-Сик И. Страх перед преступностью среди монголов на примере агломерации Улан-Батора // Евразийская интеграция: экономика, право, политика. 2021. № 1. С. $68-80$.

\section{Introduction}

Mongolia started its transition from the socialist society into a capitalism-based democratic society by changing the Mongolian Constitution in 1992. Transitional societies which have moved from authoritarian forms into democracies have often experienced increases in crime levels and problems with police reform (Bayley, 1999; Jang et al., 2015; Shaw, 2002). Since 1990, after sudden transition to the democracy, social disorganization has accelerated rapidly in Mongolia. Social changes appear to be related to a rapid increase of crime rates. As Shaw (2002) noted, a rise of crime in periods of transition is a complex phenomenon and is 
difficult to analyze because comparable statistical data on the levels of crime before and after the transition are difficult to come by, and even when available, their accuracy may be open to question.

Most studies on fear of crime have been conducted in the United States and other Western countries, as well as some East Asian countries, including China, South Korea, and Japan. As an initial effort, this study focused on understanding of fear of crime among Mongolian citizens. Research on fear of crime has not been broadly performed in Mongolia. Additionally, Mongolia has no long tradition of participating in international crime victim surveys, nor has it a regular program for national crime victim surveys. However, there are some descriptive studies: for instance, Nyamsuren (2005) noted that the result of the crime victimization research from 2003 showed that actual criminal victimization is 2.5-3 times higher than registered crime rates documented by the National Police Agency. Davaa and Altangerel (2015) provided a comparative analysis on general fear in various categories in the Mongolian society. The final result showed that 32.6 percent of Mongolian people are afraid of crime and 5.4 percent are afraid of strangers in their society. Later, Chuluunbat and Lee (2016) reported two separate studies titled "Fear of Crime in a Transitional Society: The Case of Mongolian Citizens" (2016) and "Fear of Crime among Mongolian Immigrants in Seoul, Korea" (2016).

As a result of modernization and urbanization processes in the metropolitan city of Mongolia, Ulaanbaatar, it also experiences a great increase in crime to the point that more than a half of entire registered crime in Mongolia is occurring in this capital city, while the city's population accounts for roughly one third of the population of Mongolia. The average of index crime rates per 100.000 for the entire nation was 769 within 2003 and 2014 and for the same period of time the index crime rate for Ulaanbaatar metropolitan area was 975. Official data show a significantly higher volume of crime in the capital city than in any other areas throughout the country. According to the Mongolian National Police Agency report (2015), on the average 54.2 percent of entire registered crimes between 2003 and 2014 were committed in the Ulaanbaatar metropolitan area only. Discussion of the topic of fear of crime in the Mongolian context is quite timely and appropriate to deal with.

The importance of the current study is that it is the first attempt in Mongolia to explain fear of crime and to test an integrated model using the first scientific crime victimization survey data which were collected from interviews with 683 citizens of the Ulaanbaatar metropolitan area.

Moreover, this study is the first report to address the mediating effects of collective efficacy and behavioral adaptation on the relationships between perceived incivility and fear of crime in an East Asian country.

\section{Literature review: Conceptual models of fear of crime}

The literature on the fear of crime has a substantial and significant history, with an increased presence since the 1960s (Grubb \& Bouffard, 2014; Hale, 1996) which has been received significant attention from researchers and policy makers more than five decades. Researchers have developed several distinct models to explain factors and predictors of fear of crime (McGarrell et al., 1997; Taylor \& Hale, 1986). These models have emerged as the most prominent explanations of fear of crime (Taylor \& Hale, 1986), including victimization, disorder, and community concern / control, risk interpretation models. Among these four models, most traditional, victimization model mainly focused on direct relation between direct or indirect experiences with crime and fear, whereas the disorder model identified physical and social characteristics of communities as significant predictors of fear of crime. The community concern/control model proposes perceptions of the deterioration of social control in the community as a main cause on fear (Hwang, 2006) and community residents, local police, and other public service providers as significant predictors to fear of crime (McGarrell et al., 1997; Skogan \& Maxfield, 1981; Taylor \& Hale, 1986). Finally, 'the risk interpretation model' proposed by Ferraro (1995), considered both macro and micro conditions, as well as perceived risk and behavioral adaptation as causal predictors on fear.

The Victimization Model: This model focuses on the direct relationship between victimization and fear (Hale, 1996). According to the victimization model, fear of crime is explained as the result of experiences of victimization which are direct or indirect (Skogan and Maxfield, 1981). This model attempts to address the effect of personal experience of victimization and vicarious experiences with victimization through stories of 
people they know or the media (Hale, 1996; Hayman, 2011; Hwang, 2015, Sookram et al., 2011). Some scholars reported prior victimization is directly related to fear (Hale, 1996; Ollenberger, 1981; Skogan and Maxfield, 1981), but other researchers noted previous victimization is related weakly (Garofalo, 1979: McGarrell et al., 1997). Taylor and Hale (1986) reported that 'indirect victimization perspective, for specifying the crime-fear linkage, despite recognition that connection is not straightforward, is the key focus'.

The Disorder / Incivility Model: 'Fear of crime is actually presentation of incivilities or disorder' (Hale, 1996). The disorder/incivility perspective emphasizes the relationship between social and physical incivilities and crime. Social disorder is a behavior or situation that people can see and experience, such as public drinking, loud parties, prostitution, panhandling, and drug dealing in the street, etc., whereas physical disorder involves visual signs of negligence and unchecked decay, such as abandoned or ill-kept buildings, broken streetlights, lots filled with trash or graffiti, and alleys strewn with garbage (Hwang, 2015; Karakus et al., 2010; LaGrange et al., 1992; Ross and Jang, 2000; Skogan, 1990). The thesis that perceived disorders in the neighborhood increase fear of crime has been widely supported (Franklin et al., 2008; Gibson et al., 2002; Hale, 1996; McGarrell et al., 1997).

The Community Concern / Control Model: 'The idea that explanations for crime itself may be found in loss of social control, both formal and informal, at the neighborhood level has a long and respectable history' (Hale, 1996). In prior studies, social disorganization theory (Shaw and McKay, 1942) has equally explained crime and delinquency and fear. Several studies show erosion of social control (Franklin et al., 2008), social instability, and moral decline (Gainey et al., 2011) facilitate fear of crime while social ties or social integration (Gibson et al., 2002; Lewis and Salem, 1986), neighborhood collective efficacy (Gibson et al., 2002), and confidence in the local police (McGarrell et al., 1997) inhibit fear of crime.

The Risk Interpretation Model: The risk interpretation model is 'the result of the ten-years research odyssey examining the phenomenon of fear of crime' (Ferraro, 1995), due to extend the inquiry beyond the question, 'why the elderly is so fearful of crime' even though their actual perceived risk is low'. This model was unique for using concepts and variables from macro and micro levels of sociological analysis in an integrated framework, more comprehensive than three separate models by Taylor and Hale (Lee, 1998). Major factors of this model were risk assessment and behavioral adaptations. Ferraro's model has several advantages: first, systemized interpretive processes distinguishing judgments of risk from feeling of fear, as two distinct perceptions; second, it included a consideration of the effects of objective environmental factors such as crime rates and other community characteristics while compounding perceptions of neighborhood incivilities; third, his model concerned itself with the effect of behavioral adaptations as another possible reaction to perceived risk (Lee, 1998).

The Vulnerability Thesis: Research on demographics of fear has been related to vulnerability: those who feel more vulnerable to crime are more likely to be fearful. Substantial studies have reported that women and older people are more likely to be fearful of crime (Gainey et al., 2011; Hindelang et al., 1978; Kennedy \& Silverman 1985; Taylor \& Hale, 1986; Warr, 1984). The concept of perceived vulnerability has been further differentiated between physical and social vulnerability. Physical vulnerability pertains to the perception of increased risk of being physically assault (Franklin et al., 2008) and is generally measured based on demographic characteristics (Skogan \& Maxfield, 1981). Social vulnerability assumes that those who live in disadvantaged areas (Pantazis, 2000; Skogan \& Maxfield, 1981) such as high-crime neighborhoods and are economically distressed would be vulnerable because of their everyday living circumstances and routines.

The Broken Windows Theory: The broken windows theory originally came from a seminal article by James Q. Wilson and George Kelling, which was published in the Atlantic Monthly, 1982. They advanced Shaw and McKay's (1942) social disintegration idea and pointed out that the police organization could more effectively fight against crime by focusing on even more minor annoyances in communities. Moreover, broken windows theory argues that a single broken window left untended is a sign that nobody cares and it invites more broken windows and crime generally. Disorderly behavior left untended is a sign of official disregard and it leads to fear of crime. Wilson and Killing (1982) reported in their classical work that physical and social incivilities have strong positive relationships with fear of crime. 
In this study, we tested an integrated model based on theoretical background (e.g. combined aspects of disorder theory, community concern, victimization, risk interpretation model, and broken windows theory) by using structural equation modeling.

\section{Method}

Fear of crime is an important issue as it is not limited to individual psychological safety but expands to the emotional well-being and even to life satisfaction. The study has two objectives. First, we try to testify and compare some conceptual models of fear of crime Disorder, Community concern, Victimization, and Risk interpretation, against the Vulnerability thesis and Broken windows theory. Second, we will discuss the mediating effects of collective efficacy and behavioral adaptation on the relationships between Perceived incivility and Fear of crime. Moreover, this study is the first report to address the mediating effects of collective efficacy and behavioral adaptation on the relationships between perceived incivility and fear of crime. The concept of collective efficacy emerged from social disorganization literature and it means social control exerted by cohesive community stakeholders, based on mutual trust, including intervention in the supervision of children and maintenance of public order (Sampson et al., 1999). Collective efficacy refers to a collective ability of residents to produce a social action to achieve common objectives and preserve shared values. Fear of crime refers to a wide variety of subjective and emotional assessments and behavioral reports (DuBow et al., 1979). People who fear of crime tend to constrain their behavior to safe areas during safe times and avoid unsafe areas (Liska et al., 1988). Moreover, fear and constrained behavior are a positive escalating loop: fear causes people to constrain their behavior and this behavior response in turn heightens their fear (Liska et al., 1988).

The study used data from the survey titled as a "Crime Victimization Survey". The survey was implemented in the Ulaanbaatar city, Mongolia, during September, 2015 utilizing a stratified random sampling method. The Ulaanbaatar is the largest city of Mongolia, with 1.3 million people which is almost a half of the population of Mongolia (Mongolian National Statistics Office, 2014). The Ulaanbaatar metropolitan area is administratively divided into nine districts: Baganuur, Bagakhangai, Bayanzurkh, Bayangol, Chingeltei, Khan-Uul, Nalaikh, Songino-Khairkhan, and Sukhbaatar. Additionally, each district is subdivided into several Khoroos (Sub-District) and there are 138 khoroos in total. Researchers selected six most densely populated districts out of nine. After selecting districts, researchers selected five main khoroos from each district. The survey was based on both door-to-door interviews and paper and pencil survey method with individuals and their family members 14 years of age and above participating.

Before conducting the survey, a short-term advisory-training was provided to the research staff in order to ensure the quality of the survey. The survey contains an approximately 80 item questionnaires based on a developed review of the International Crime Victim Survey. The questionnaire was originally built in English and was translated into the Mongolian language by bilingual scholars and reviewed by university level linguists. In the absence of any previous Mongolian studies of this type, scholars faced some difficulties in translating specific definitions and proper naming of some variables in Mongolian language. The survey was conducted during 25 days. A total of 700 responses gathered of these 17 were discarded due to their poor quality.

Variables and Measurements: This study conducted Exploratory Factor Analysis (EFA) for examining construct validities and construct equivalences. As Kline (1994) suggested, a moderately high value of 0.30 is the cut-off value for the accepted factor loading with varimax rotation employed in this study (Cheung et al., 2003). Respective varimax rotation is an orthogonal rotation technique which aimed to maximizing the sum of variances of squared loadings in the columns of the factor matrix. The Cronbach's a scores in each factor were higher than the recommended 0.70 cut-off value (Nunnally \& Bernstein, 1994) and all results indicating that the measurement scales employed in the model can be considered to be a valid operationalization of the latent construct.

Dependent Variable: The dependent variable of the current study is fear of crime. The study adopted the global measures of fear of crime. Fear of crime at home was measured using the question "How much are you 
fearful in each situation? - When I am staying home alone at night". It was measured on the bases of the five points scale, $1=$ strongly not fearful, $2=$ not fearful, $3=$ =neutral, $4=$ fearful, and $5=$ strongly fearful. Fear of crime on the street was measured using the question "How much are you fearful in each situation? - When I am walking alone on the neighborhood street at night". It was measured on the bases of the five points scale. The Cronbach's alpha for the scale was .774. Exploratory factor analysis with varimax rotation method also showed that these two items were associated with single latent construct (factor loadings .903).

Independent Variables: This study included independent variables of perceived incivility, victimization, collective efficacy, behavioral adaptation, and control variables of age and gender.

The Perceived Incivility is a factor-based scale, which is a measure of citizens' perceptions in their neighborhood about physical and social incivilities. The following six survey items were used to reflect both physical and social incivilities: For the physical incivility: 1) My neighborhood is dirty with rubbish; 2) There are many dark and ignored places; 3 ) There are empty buildings and neglected cars; For the social incivility: 1) There are many people breaking basic orders (ex, jaywalking, illegal parking); 2) I often see groups of delinquent juveniles wandering around; 3 ) I often see people fighting or quarreling. Each item was measured based on the five points scale: $1=$ strongly disagree, $2=$ disagree, $3=$ =neutral, $4=$ agree, and $5=$ =strongly agree. The perceived incivility scale was alpha of .779. Exploratory factor analysis with varimax rotation method indicated that these items were associated with single latent construct (factor loadings $>.648$ ).

The Direct Victimization experiences are divided into two categories, property and violent crime victimization during the past one year (2014). The dummy-coded four items - fraud, theft, burglary, and vandalism are added for the property crime victimization variable, while the other dummy-coded four items - assaulted / threatened / robbed at places, assaulted / threatened / robbed with tools, assaulted / threatened / robbed by acquaintances, and unwanted sexual contact by force - are added for the violent crime victimization variable. Respondents were asked to indicate their experiences based on the scale yes $=1$, no= 0 . The scale of Cronbach's alpha was .675 and the exploratory factor analysis with varimax rotation method indicated factor loadings of $>.445$.

The Collective Efficacy's measure was modeled like other researchers (Sampson \& Raudenbush, 1999) and included a series of questions of social cohesion and informal social control. The perception of community cohesion among neighbors is a factor-based scale measured by three question items: 1) Residents in my neighborhood know about each other; 2) Residents in my neighborhood talk about community issues; 3) Residents in my neighborhood help each other with difficulties. Each item was measured based on the five-point scale: $1=$ strongly disagree, $2=$ disagree, 3=neutral, 4=agree, and 5=strongly agree. The perception of informal social control among neighbors is a factor-based scale measured by three question items: 1) Residents in my neighborhood are willing to help children in the case that they are bullied; 2) Residents in my neighborhood seem to call the police if they see a crime happening; 3 ) Residents in my neighborhood are willing to join volunteer patrol activities for crime prevention. Each item was measured based on the five-point scale: $1=$ =strongly disagree, $2=$ disagree, $3=$ neutral, $4=$ agree, and $5=$ strongly agree. The collective efficacy scale was alpha of .678. Exploratory factor analysis with varimax rotation method indicated that these items were associated with single latent construct (factor loadings>.667).

The Behavioral Adaptation the subjects were asked to indicate how they undertook four specific actions to prevent themselves from the possible crime or violence victimization. A factor-based scale measured by four question items related to avoidance behavior. 1) I ask somebody accompany me when I go out late at night; 2) I avoid dangerous places not to be victimized; 3) I postpone something to avoid going out at night; 4) I avoid taking a taxi alone at night. Each item was measured based on the five points scale: $1=$ strongly disagree, $2=$ disagree, $3=$ neutral, 4=agree, and 5=strongly agree. Avoidance strategy might be the most effective case in a reality and it includes the minimization of activities in hot spot areas such as disorderly neighborhood, entertainment places, and parks, and particular types of people such as strangers, groups of youngsters, and beggars, as well as avoidance of routine activities such as travelling on public transportation or shopping at particular stores (Jonathan \& Ioanna, 2013). The behavioral adaptation scale was alpha of .719. Exploratory factor analysis with varimax rotation method indicated these items were associated with single latent construct with factor loadings $>.640$. 
Data Analysis Technique: Statistical analyses of the study were conducted by using SPSS and AMOS. The study was utilized Structural Equation Modeling (SEM) to examine whether the fear of crime factor structure has been defined by the hypotheses of model to fit the data. Based on general assumption (James et al., 1982; Kline, 2005; Schumacker \& Lomax, 2004) two-step approach is conducted. First, we establish the measurement model for the constructs by utilizing confirmatory factor analysis (CFA). Second, the structural model is tested to examine the hypothesized relationship between incivility, victimization, collective efficacy, behavioral adaptation and fear of crime. Finally, the study examined the effects of control variables of age and gender by employing an integrated model.

Additionally, before conducting above mentioned analyses, two diagnostic procedures were produced in order to obtain understanding about a general characteristic.

\section{Findings}

General Characteristics: Descriptive statistics for the variables used in the analysis are reported in the Table 1. For the dependent variables, the mean of fear on the street is higher than the mean of fear at home (3.2 vs 2.4). The fear of crime at home had a mean score of 2.43 (S.D.=1.042). Among respondent's 14.3 percent of them reported that they experienced fear, whereas 2.9 percent felt strong fear while staying at home at night. The fear of crime on the street in the neighborhood area had mean score of 3.2 (S.D.=1.046), which was somewhat above the midpoint. A 33.7 percent of residents reported that they were fearful at night in the neighborhood area, whereas 8,8 percent of them expressed strong fear.

Table 1

\section{Descriptive Statistics}

\begin{tabular}{|c|c|c|c|c|}
\hline Variables & Min & Max & Mean & S.D. \\
\hline \multicolumn{5}{|l|}{ Dependent Variables } \\
\hline Fear at home & 1.00 & 5.00 & 2.4389 & 1.04287 \\
\hline Fear on the street & 1.00 & 5.00 & 3.2018 & 1.04600 \\
\hline \multicolumn{5}{|l|}{ Independent Variables } \\
\hline Physical incivility & 3.00 & 15.00 & 9.1523 & 2.63776 \\
\hline Social incivility & 3.00 & 15.00 & 9.1408 & 2.56370 \\
\hline Victimization of property crime & .00 & 4.00 & 0.9906 & 1.01884 \\
\hline Victimization of violent crime & .00 & 4.00 & 0.4480 & 0.85448 \\
\hline Community cohesion & 3.00 & 15.00 & 8.2630 & 2.79953 \\
\hline Informal social control & 3.00 & 15.00 & 9.0711 & 2.61783 \\
\hline Behavioral adaptation & 4.00 & 20.00 & 11.8420 & 2.98553 \\
\hline \multicolumn{5}{|l|}{ Control Variables } \\
\hline Age & 14 & 87 & 34.3414 & 13.17180 \\
\hline Gender (Female) & .00 & 1.00 & 0.5385 & 0.49632 \\
\hline
\end{tabular}

The perceived physical incivility had a mean score of 9.15 (S.D.=2.63). The average level of physical incivility among respondents was 3.05 points (mean / number of items) in the five points scale per item for all 3 items. (1=strongly disagree, $2=$ disagree, $3=$ neutral, $4=$ =agree, and $5=$ strongly agree). On the social incivility, a mean score was 9.14 (S.D. $=2,56$ ) which was slightly above the midpoint. The average level of social incivility among respondents was 3.04 points (mean / number of items) in the five points scale (1=strongly disagree, $2=$ disagree, $3=$ neutral, 4=agree, and 5=strongly agree) per item for all 3 items. Respondents experienced about two times more property crime than violent crime in 2014 year. Mean score for the property crime victimization was 0.99 (S.D. $=1.01$ ), and for the violent crime victimization was 0,44 (S.D. $=0.85$ ). The average 
assessment on the community cohesion was 8.26 (S.D.=2.79). The average level of community cohesion among respondents was 2,75 points (mean / number of items) in the five points scale (1=strongly disagree, 2=disagree, $3=$ neutral, $4=a g r e e$, and $5=$ strongly agree) per item for all 3 items. Informal social control had a mean score 9.07 (S.D.=2.61). The average level of informal social control among respondents was 3.02 points (mean / number of items) in the five points scale ( 1 =strongly disagree, $2=$ disagree, $3=$ neutral, $4=$ =agree, and $5=$ strongly agree) per item for all 3 items. Respondents reported that 11.8 percent (S.D. $=2.98$ ) of them had experienced behavioral adaptation. The average level of behavioral adaptation among respondents was 2.96 points (mean / number of items) in the five points scale ( 1 =strongly disagree, $2=$ disagree, $3=$ neutral, $4=$ =agree, and $5=$ =strongly agree) per item for all 4 items.

For the control variables, the mean age was 34.3 (S.D.=13.17). The age of respondents was distributed between 14 and 87 years. Among the total respondents, 46.2 percent were males and 53.8 percent were females, which means females are a little bit more than male representatives (S.D. $=0.49$ ).

\section{Bivariate Correlation}

Correlation between Variables: $\mathrm{N}=683$

\begin{tabular}{|c|c|c|c|c|c|c|c|c|c|c|}
\hline Variables & 1 & 2 & 3 & 4 & 5 & 6 & 7 & 8 & 9 & 10 \\
\hline 1. Fear at home & 1 & & & & & & & & & \\
\hline 2. Fear on the street & $.632^{* *}$ & 1 & & & & & & & & \\
\hline 3. Incivility-physical & $.204^{* *}$ & $.302 * *$ & 1 & & & & & & & \\
\hline 4. Incivility-social & $.182^{* *}$ & $.279 * *$ & $.507^{* *}$ & 1 & & & & & & \\
\hline 5.Victimization-property crime & .048 & -.036 & $.121^{* *}$ & $.148 * *$ & 1 & & & & & \\
\hline 6. Victimization-violent crime & .083 & .032 & .039 & $.115^{* *}$ & $.406 * *$ & 1 & & & & \\
\hline 7. Community cohesion & -.040 & $-.133^{* *}$ & -.031 & $-.092 *$ & $-.089 *$ & -.003 & 1 & & & \\
\hline 8. Informal social control & $-.129 * *$ & $-.171^{* *}$ & -.071 & $-.116^{* *}$ & $-.097^{*}$ & -.011 & $.514^{* *}$ & 1 & & \\
\hline 9. Behavioral adaptation & $.302 * *$ & $.397 * *$ & $.144^{* *}$ & $.103^{* *}$ & .004 & .015 & .017 & .006 & 1 & \\
\hline 10. Age & $.084^{* *}$ & .068 & $.124^{* *}$ & $.142^{* *}$ & $-.093^{*}$ & -.065 & .070 & $.134^{* *}$ & .945 & 1 \\
\hline
\end{tabular}

Table 2 shows the results of a bivariate correlation analysis among variables, which was performed in order to investigate the simple correlation between variables. The result indicates that most of independent variables have significant relationships with dependent variable except community cohesion and victimization of property and violent crimes. Moreover, physical incivility, social incivility, property crime victimization, violent crime victimization, and behavioral adaptation have positive relationships with the fear of crime at home, while other variables did not. In the case of street level fear, physical incivility, social incivility, community cohesion, informal social control, and behavioral adaptation showed significant relationships, while other variables did not. Also, a multi-collinearity was not a problem considering the VIF (variance of inflation factor) scores which were less than 2.0 (Stevens, 1992) in all relationships.

Measurement Model Results: Before testing the final structural model, the measurement models were examined. A measurement model is confirmatory factor model which is to discover the reliability and validity of the observed variables in the relation to the latent variable. Literature review (Byrne, 2006) suggests that each latent variable should be represented by multiple (at least three) indicators. In this study measurement models tested using confirmatory factor analysis (CFA) followed as literature suggested, each latent variable should be represented by multiple (at least three) indicators. In this respect, global fear of crime variables could not be analyzed, as well as victimization variables due to dummy coded. Consistently, perceived incivility, collective efficacy, and behavioral adaptation were analyzed with a good fit model.

The Perceived Incivility is a factor-based scale, which is a measure of citizens' perceptions in their neighborhood, about physical and social incivilities. The perceived incivility scale was alpha of .779. Exploratory 
factor analysis with varimax rotation method indicated that these items were associated with single latent construct (factor loadings $>$.648). The result showed a good model fit with an RMSEA of $.042^{1}$. The results of the goodness of fit for the measurement model tested using CFA indicated chi-square $11.038\left(x^{2}\right)$; degree of freedom 5; $p$ value .051; chi-square/degree of freedom ratio $\left(\mathrm{x}^{2} / d f\right)$ 2.208; goodness of fit (GFI) .995; comparative fit of index (CFI) 0.994 and, Tucker-Levis Index (TLI) .981 which can be considered to be valid operationalization of the latent construct.

The Collective efficacy scale was alpha of .678. Exploratory factor analysis with varimax rotation method indicated that these items were associated with single latent construct (factor loadings>.667). The collective efficacy factor contains a series of items on the survey which asked issues about community cohesion and informal social control. It indicated a good model fit with an RMSEA of .035. The results of the goodness of fit for the measurement model tested using CFA showed chi-square $7.387\left(x^{2}\right)$; degree of freedom 4; $p$ value .117; chisquare / degree of freedom ratio ( $\left.\mathrm{x}^{2} / d f\right)$ 1.847; goodness of fit (GFI) .996; comparative fit of index (CFI) .997 and, Tucker-Levis Index (TLI) .991 which can be considered to be a valid operationalization of the latent construct.

The Behavioral adaptation scale was Cronbach's alpha of .71. Exploratory factor analysis with varimax rotation method indicated these items were associated with single latent construct with factor loadings >.640. The model fit was good with an RMSEA of .065. The result of the goodness of fit for the measurement model test CFA showed chi-square $7.680\left(\mathrm{x}^{2}\right)$; degree of freedom 2; $p$ value .021 chi-square / degree of freedom ratio $\left(x^{2} / d f\right)$ 3?840; goodness of fit (GFI) .995; comparative fit of index (CFI) .998 and, Tucker-Levis Index (TLI) .968 which can be considered to be a valid operationalization of the latent construct.

As outlined above, this study used wealth of data. The data were used in a host of structural equation models which designed to test the relationships between incivility, victimization, collective efficacy, behavioral adaptation, and fear. The structural model was analyzed to test model fit results of the proposed theoretical model based on an integrated model.

Structural Model Results: The structural models of the study were begun by testing relationships between variables of the full path model, model with significant paths, full path model with control variables, and final model with control variables. All estimates are standardized, as the latent factors themselves were standardized in the CFA analyses. In the model variables were presented as in abbreviations INC-Incivility; BA-Behavioral Adaptation; FOC-Fear of Crime; COE-Collective Efficacy; VIC-Victimization. After elimination of non-significant relationships from the models the final model is depicted with only statistically significant standardized path coefficients including four latent constructs in the hypothesized model namely incivility, collective efficacy, behavioral adaptation, and fear of crime with control variables.

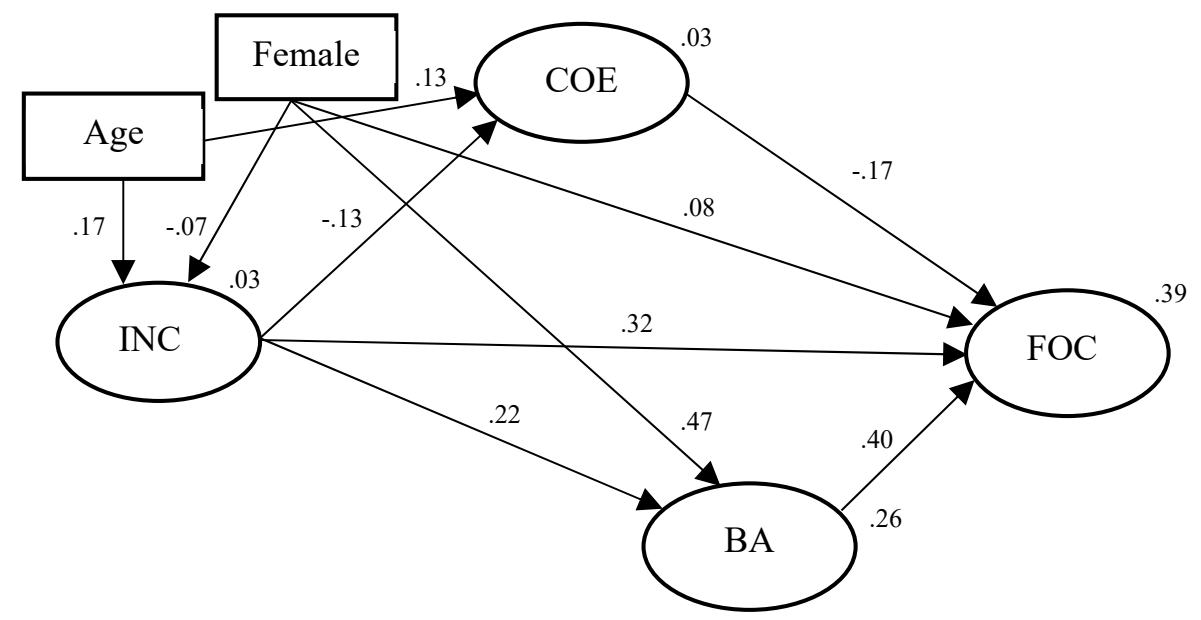

Fig. 1. Final model with control variables

1 An RMSEA of less than or equal to .06 is defined as a good model fit. 
The result showed that a good model fit with an RMSEA of .033, chi-square $78.349\left(x^{2}\right)$; degree of freedom 45; $p$ value .002; comparative fit of index (CFI) .980, Tucker-Levis Index (TLI) .971, Normed fit index (NFI) .956, and Relative fit index (RFI) .935.

Incivility has statistically significant direct effects on fear of crime $\left(.325^{* *}\right)$, collective efficacy $\left(-131^{*}\right)$, and behavioral adaptation $\left(.219^{* *}\right)$. Behavioral adaptation has a strong positive direct effect $\left(.400^{* * *}\right)$ on fear of crime, whereas collective efficacy has a significant negative effect $\left(-.166^{* *}\right)$ on fear of crime. Finally, it considered that perceived incivility has significant indirect effect on fear of crime $\left(.434^{* *}\right)$ through both behavioral adaptation and collective efficacy.

The final model indicated significant relationships between variables. Overall models presented in the study mainly supported research purposes, consistent with theoretical assumptions. There exists significant indirect impact from perceived incivility to fear of crime through collective efficacy and behavioral adaptation. As previous literature suggested, the models showed supportive readings of indirect effects of perceived incivility to fear of crime as predicted by the broken windows theory. The best fitting final model suggested that perceived incivility affects not only indirectly the fear of crime by mediation of behavioral adaptation and collective efficacy, but also it has strong significant direct effects on behavioral adaptation, collective efficacy, and fear of crime themselves. Moreover, behavioral adaptation and collective efficacy have significant direct relationships to fear of crime.

\section{Discussion and Conclusion}

This study is an initial attempt to explore an understanding of fear of crime among Mongolian citizens by testing an integrated model. The study used data from the survey which was implemented in Ulaanbaatar, Mongolia, during September, 2015. Building on previous studies, a modified version of crime victim survey questionnaires was used to collect data. An integrated model based on theoretical background (e. g. combined aspects of disorder theory, community concern, victimization, risk interpretation model, broken windows theory), was employed to examine mediating effects of behavioral adaptation and collective efficacy among incivility and fear of crime. Fear of crime was measured on by global scales: regarding individuals' relative degree of fear at home and on the neighborhood street at night.

The previous studies have noted that perceived incivilities in neighbor areas increase fear of crime (Franklin et al., 1989). As previous literature suggested, the models showed supportive readings of indirect effects of perceived incivility upon fear of crime which is most remarkably consistent with broken windows theory. The best fitting final model suggested that perceived incivility effects not only indirectly fear of crime by mediating behavioral adaptation and collective efficacy, but also it has strong significant direct effects on behavioral adaptation, collective efficacy, and fear of crime.

An effect of collective efficacy was interesting. While previous literature suggested that higher collective efficacy can cause the crime reduction. Consistent with the broken windows theory the present study found that collective efficacy indicators have a direct negative relationship to perceived incivility and fear of crime (Cohen et al., 2000; Raudenbush \& Sampson 1999). Results showed an indirect path from perceived incivility to fear of crime through collective efficacy.

The effect of victimization is not a significant predictor in the research model. Prior victimization in this study supported some scholars reports, which are that victimization experiences did not stimulate the feeling of fear of crime - or that the relationship was very weak (Garofalo, 1979; Katz et al. 2003; Lewis \& Salem1986; Liska et al., 1988; McGarrell et al., 1997; Minnery \& Lim 2005; Rifai, 1982; Skogan, 1987; Skogan \& Maxfield 1981).

Behavioral adaptation has a strong significant relation on incivility and gender, and fear. Behavioral adaptation mediated the relationship between incivility and fear. People who fear crime tend to constrain their behavior to safe areas during safe times and avoid unsafe areas. Fear and constrained behavior are a positive escalating loop: fear causes people to constrain their behavior and this behavior response in turn heightens their fear (Liska et al., 1988). 
Previous studies reported that the neighborhood's perception of crime and an individual's characteristics, such as age and gender, have had mixed results. Most previous studies reported that women are more fearful of crime than men. Women are more concerned with sexual vulnerability due perceived increased levels of fear in unknown or disordered places (LaViolette \& Barnett 2000). The findings of the current study showed that gender (female) is one of the most important predictors of fear of crime both at home and on the neighborhood street at night. Consistent with broken windows theory, gender has a strong relationship with both incivility and behavioral adaptation. Overall, results of the study were consistent with previous studies which reported that women are more fearful of crime than men (Balkin, 1979; Garofalo, 1981; Gordon \& Riger, 1989; Lee \& Ulmer, 2000; Stafford \& Galle, 1984). It is important to note, as an aside, that like the rest of the world, in Mongolia, many violent crimes against women are not reported or documented.

The findings showed that there is not a significant relationship between age and fear in the context of traditional Mongolia. The majority of Mongolian families are multigenerational and the elderly people are living in a caring and nurturing environment, and are not as isolated as in western societies where the elderly mostly live by themselves (Chuluunbat \& Lee, 2016). This result is very similar to Hwang's (2006) study of fear of crime in the traditional society of South Korea. However, age has strong significant relation with incivility and collective efficacy which could be construed that aged reactions are dependent on incivility and collective efficacy.

It is important to discuss a policy implication of this study. Public opinion about issues of crime in transitional societies is critical (Shaw, 2002). The first policy implication of the study focused on broken windows theory. As literature suggested disorderly behavior untended leaves residents afraid or frightened, causing them withdraw from their community, and leads to fear of crime, more serious crime and, ultimately, urban decay. Considering this, if police and residents are able to co-operate in managing a minor incivility, the result could be to effectively reduce delinquent or criminal activity. Second, the study suggested theoretical and methodological improvements to evaluate accuracy, usefulness, and reliability of the future studies. Expanding a sample size by investigating related issues, co-operation with governmental statistics offices for investigating types of index crimes, and improvement of data collection strategies are also respectively taken into consideration. Finally, further research would be well to expand upon the present study in other transitional societies using more accurate and comprehensive data sets in order to confirm these findings.

This study has several limitations. The first and main limitation of this study was a non-significant relationship between victimization and fear of crime and no mediating effect of victimization between incivility and collective efficacy to fear, whereas, much previous literature reported that direct victimization is a significant predictor of fear of crime (Bursik \& Grasmick, 1993; Ferraro 1995; Gray et al., 2006; Katz et al., 2003; Skogan, 1986, 1987; Skogan \& Maxfield, 1981). Future research may benefit from exploring victimization in relation to the fear of crime and may address the effect of incivility on fear through victimization. The second potential limitation of this study deals with relationship between age and fear. Most previous studies have found a significant relationship between age and fear of crime. The elderly is more fearful of crime due to physical disabilities as a result of their age (Hinderland et al., 1978). One of the possible explanations for a non-significant association between these two variables in this research may be participants' age distribution differences. Our age distribution was, 43.3 percent between 14-30 years old, 43.8 percent 31-50 years old, and 12.9 percent more than 51 years old. Future work may explore this issue by re-considering participants' age distribution. Also, as noted before, the majority of Mongolian families are multigenerational and the elderly people are not as lonely as in western societies where the elderly mostly live by themselves (Chuluunbat \& Lee, 2016). Of course one of the limitations of this study is the relatively modest sample from which data was collected from the residents in the Ulaanbaatar metropolitan area. Finally, a lack of national level crime victimization surveys is another limitation.

In conclusion, this study tried to enlarge our body knowledge about fear of crime and its predictors among non-Western citizens such as Mongolians while testing an integrated model of fear of crime over a fairly different population from those of the previous research. The result of the current study may offer understanding not only of public opinion toward crime but also suggests policy implications for law enforcement agencies of Mongolia. 


\section{References}

1. Balkin S. (1979). Victimization Rates, Safety and Fear of Crime. Social Problems, 26, pp. 343-358.

2. Bayley D. H. (1975). The Police and Political Development in Europe: The Formation of National States in Europe. Princeton, NJ : Princeton University Press.

3. Bursik R. J., Grasmick H. G. (1993). Neighborhoods and Crme: The Dimensions of Effective Community Control. New York : Lexington Books.

4. Cheung F., Cheung S., Leung K., Ward C., Leong F. (2003). The English Version of the Chinese Personality Inventory. Journal of Cross-Cultural Psychology, 34, pp. 433-452.

5. Chuluunbat Sh., Lee Min-Sik (2016). Fear of Crime in a Transitional Society: The case of Mongolian Citizens. Journal of Korean Association for Terrorism Studies, 9 (2), pp. 77-95.

6. Chuluunbat Sh., Lee Min-Sik (2016). Fear of Crime among Mongolian Immigrants in Seoul Metropolitan Areas. Korean Journal for Public Security and Criminal Justice, 63, pp. 239-265.

7. Cohen D., Spear S., Scribner R., Kissinger P., Mason K., Wildgen J. (2000). Broken Windows and the Risk of Gonorrhea. American Journal of Public Health, 90, pp. 230-236.

8. Davaa J., Altangerel B. (2015). The Fear in Mongolian Society: Comparative Analysis. Asian Journal of Social Sciences and Humanities, 4 (2), pp. 145-153.

9. DuBow F., McCabe E., Kaplan G. (1979). Reactions to crime: A Critical Review of the Literature. Washington, D.C.: National Institute of Law Enforcement and Criminal Justice, U.S. Government Printing Office.

10. Ferraro K. F. (1995). Fear of Crime: Interpreting Victimization Risk. New York : SUNY Press.

11. Franklin T. W., Franklin C. A., Fearn N. E. (2008). A Multilevel Analysis of the Vulnerability, Disorder, and Social Integration Models of Fear of Crime. Social Justice Research, 21 (2), pp. 204-227.

12. Gainey R., Alper M., Chappell A. T. (2011). Fear of Crime Revisited: Examining the Direct and Indirect Effects of Disorder, Risk Perception, and Social Capital. American Journal of Criminal Justice, 36 (2), pp. 120-137.

13. Garofalo J. (1979). Victimization and the Fear of Crime. Journal of Research in Crime and Delinquency, $16(1)$, pp. 80-97.

14. Garofalo J. (1981). The Fear of Crime: Causes and Consequences. Journal of Criminal Law and Criminology, $72(2)$, pp. 839-857.

15. Gibson C. L., Zhao J., Lovrich N. P., Gaffney M. J. (2002). Social Integration, Individual Perceptions of Collective Efficacy, and Fear of Crime in Three Cities. Justice Quarterly, 19 (3), pp. 537-564.

16. Gordon M. T., Riger S. (1989). The Female Fear. New York : The Free Press.

17. Gray E., Jackson J., Farrall S. (2006). Reassessing the Fear of Crime: Frequencies and Correlates of Old and New Measures. Experience and Expression in the Fear of Crime. Working Paper, 3.

18. Grubb J. A., Bouffard L. (2014). The Interrelationships between Victimization, Fear and Acculturation among Asian Immigrants. Victims and Offenders: An International Journal of Evidence-based Research, Policy, and Practice, 9 (4), pp. 353-385.

19. Hale C. (1996). Fear of Crime: A Review of the Literature. International Review of Victimology, 4, pp. 79150.

20. Hinderland M. J., Gottfredson M. R., Garofalo J. (1978). Victims of Personal Crime. Cambridge, MA : Ballinger.

21. Hwang E. G. (2015). A Bi-National Comparative Study about the Fear of Crime among Korean Immigrants in the Detroit Metropolitan Area. USA and Native Korean Immigrants in Seoul, South Korea. Journal of Policing, 3, pp. 231-275.

22. Hwang E. G. (2006). A Multilevel Test of Fear of Crime: The Effect of Social Conditions, Perceived Community Policing Activities, and Perceived Risks in a Megalopolis. Doctoral Dissertation. Michigan State University, East Lansing.

23. Jang Hyun-Seok, Enkhbold B., Chuluunbat Sh. (2015). Trust in the Police in a Transitional Society: The Case of Mongolia. Journal of Korean Criminological Association, 9 (2), pp. 280-308.

24. James L. R., Mulaik S. A., Brett J. M. (1982). Causal Analysis Assumptions, Models, and Data. Beverly Hills, CA : Sage. 
25. Karakus O., McGarrell E. F., Basibuyuk O. (2010). Fear of Crime among Citizens of Turkey. Journal of Criminal Justice, 38, pp. 174-184.

26. Katz C. M., Webb V. J., Armstrong T. A. (2003). Fear of Gangs: A Test of Alternative Theoretical Models. Justice Quarterly, 20 (1), pp. 95-130.

27. Kennedy L. W., Silverman R. A. (1985). Significant others and Fear of Crime among the Elderly. International Journal of Aging and Human Development, 20, pp. 241-256.

28. Kline R. B. (2005). Principles and Practice of Structural Equation Modelling. New York : The Guilford Press.

29. Kury H., Obergfell F. J., Ferdinand T. (2001). Aging and the Fear of Crime: Recent Results from East and West Germany. International Review of Victimology, 5 (1), pp. 75-112.

30. LaGrange R. L., Ferraro K. F., Supancic M. (1992). Perceived Risk and Fear of Crime: Role of Social and Physical Incivilities. Journal of Research in Crime and Delinquency, 29, pp. 311-334.

31. LaViolette A. D., Barnett O. W. (2000). It Could Happen to Anyone: Why Battered Women Stay (2nd eds.). Thousand Oaks : SAGE.

32. Lee M. (1998). Fear of Crime among Korean Americans in the Chicago Area: A Multilevel Analysis. Unpublished Doctoral Dissertation, Purdue University.

33. Lee M., Ulmer J. T. (2000). Fear of Crime among Korean Americans in Chicago Communities. Criminology, 38, pp. 1173-1206.

34. Lewis D. A. \& Salem G. (1986). Fear of Crime: Incivility and the Production of a Social Problem. New Brunswick. NJ : Transaction Books.

35. Liska A. E., Sanchirico A. \& Reed M. D. (1988). Fear of Crime and Constrained Behavior: Specifying and Estimating a Reciprocal Effects Model. Social Forces, 66, pp. 827-837.

36. McGarrell E. F., Giacomazzi A. L., Thurman Q. C. (1997). Neighborhood Disorder, Integration, and the Fear of Crime. Justice Quarterly, 14 (3), pp. 479-500.

37. Minnery J. R. \& Lim B. (2005). Measuring Crime Prevention Through Environmental Design. Journal of Architectural and Planning Research, 22 (4), pp. 330-341.

38. Mongolian National Police Agency (2015). Crime Situation in Mongolia: 2014. Mongolian National Police Agency Report, 1 (1), pp. 6-133.

39. Mongolian National Statistical Office (2015). Statistical Yearbook of Mongolia 2014.

40. Nunnally J. C., Bernstein I. H. (1994). Psychometric Theory (3rd eds.). New York: McGraw-Hill.

41. Nyamsuren Ch. (2005). Crime Victimization. Mongolian Advocates Association, Soyombo press, Ulaanbaatar.

42. Ollenburger J. (1981). Criminal Victimization and Fear of Crime. Research on Ageing, 3, pp. 101-118.

43. Pantazis C. (2000). Fear of Crime: Vulnerability and Poverty. British Journal of Criminology, 40, pp. 414-436.

44. Raudenbush S. W., Sampson R. J. (1999). Ecometrics: Toward a Science of Assessing Ecological Settings, with Application to the Systematic Social Observation of Neighborhoods. Sociological Methodology, 29, pp. 1-41.

45. Rifai M. Y. (1982). Methods of Measuring the Impact of Criminal Victimization through Victimization Surveys. H. J. Schneider (Ed.). The Victim in International Perspective. Berlin and New York : de Gruyter.

46. Ross C. E., Jang S. (2000). Neighborhood Disorder, Fear, and Mistrust: The Buffering Role of Social Ties with Neighbors. American Journal of Community Psychology, 28, pp. 401-420.

47. Sampson R. J., Raudenbush S. W., Earls F. (1997). Neighborhoods and Violent Crime: A Multilevel Study of Collective Efficacy. Science, 277, pp. 918-924.

48. Schumacker R. E., Lomax R. G. (2004). A Beginner's Guide to Structural Equation Modeling (2 $2^{\text {nd }}$ eds.), Mahwah, NJ : Lawrence Erlbaum Associates.

49. Shaw C. R., McKay H. D. (1942). Juvenile Delinquency and Urban Areas. University of Chicago Press.

50. Shaw M. (2002). Crime, Police and Public in Transitional Societies. Transformation: Critical Perspectives on Southern Africa, 49, pp. 1-24.

51. Skogan W. G. (1986). Fear of Crime and Neighborhood Change. A. J. Reiss \& M. Tonry (Eds.). Communities and crime, 203-229, Chicago : University of Chicago Press. 
Skogan W. G. (1987). The Impact of Victimization on Fear. Crime and Delinquency, 33 (1), pp. 135-154.

52. Skogan W. G. (1990). Disorder and Decline: Crime and the Spiral of Decay in American Neighborhoods. Berkeley and Los Angeles : University of California Press.

53. Skogan W. G., Maxfield M. G. (1981). Coping with Crime: Individual and Neighborhood Reactions. Sage : Beverly Hills, CA.

54. Stafford M. C., Galle O. R. (1984). Victimization Rates, Exposure to Risk, and Fear of Crime. Criminology, 22, pp. 173-185.

55. Stevens J. (1992). Applied Multivariate Statistics for the Social Sciences (2nd eds.), Hillsdale. HJ : Lawrence Erlbaum.

56. Taylor R. B., Hale M. (1986). Testing Alternative Models of Fear of Crime. Criminology, 77 (1), pp. 151-189.

57. Warr M. (1984). Fear of Victimization: Why are Women and the Elderly more Afraid? Social Science Quarterly, 65, pp. 681-702.

58. Wilson J. Q., Kelling G. L. (1982). The Police and Neighborhood Safety: broken Windows. The Atlantic Monthly, 249 (March), pp. 29-38.

\section{About the authors:}

Chuluunbat Sharkhuu, President of Mongolian Institute for Protection and Security Studies, Director of Foreign Language Institute, University of Internal Affairs (Ulaanbaatar, Mongolia), PhD in Criminology, Professor; mongolianipss@gmail.com

Min-Sik Lee, Professor of Department of Police Administration, Kyonggi University (Suwon, South Korea), PhD in Criminology; Imspu@kyonggi.ac.kr

\section{6 авторах:}

Шархуу Чулуунбат, профессор, президент Института исследования защиты и безопасности Монголии, директор Института иностранного языка, Университет внутренних дел Монголии (Улан-Батор, Монголия), доктор (PhD) криминологии, профессор; mongolianipss@gmail.com

Мин-Сик И, профессор кафедры полицейского управления Университета Кионгги (Сувон, Южная Корея), доктор (PhD) криминологии; Imspu@kyonggi.ac.kr 